\title{
Anticatalyptic Activity of Rheum emodi on Haloperidol Induced Parkinsonism
}

\author{
Pooja R. Ganeshkar*, Jivan M. Maidankar, Sachin J. Dighade, Anjali M. Wankhade \\ Institute of Pharmacy \& Research Badnera Amravati, M.S. India. \\ *Corresponding author's E-mail: poojaganeshkar@gmail.com
}

Received: 21-11-2021; Revised: 24-01-2022; Accepted: 02-02-2022; Published on: 15-02-2022.

\begin{abstract}
In the present study, we evaluated anti-Parkinson's activity of Ethanolic extract of Rheum emodi (EERE) leaves in haloperidol induced catalepsy in experimental animal models. In this study, effects of Rheum emodi (100, 200, and $400 \mathrm{mg} / \mathrm{kg}$, p.o.) were studied using in vivo behavioral parameters like catalepsy, locomotor activity, muscles coordination and its effects in rats. The experiment was designed by giving haloperidol to induce catalepsy and Parkinson's disease-like symptoms. The increased cataleptic scores (induced by haloperidol) were significantly $(p<0.001)$ found to be reduced, with the EERE at a dose of $200 \mathrm{and} 400 \mathrm{mg} / \mathrm{kg}$. significantly induced motor dysfunction (muscle rigidity and hypolocomotion). Daily administration of $\operatorname{EERE}(400 \mathrm{mg} / \mathrm{kg}$ ) significantly improved motor performance and also significantly attenuated oxidative damage. Thus, the study proved that Rheum emodi treatment significantly attenuated the motor defects and also protected the brain from oxidative stress.
\end{abstract}

Keywords: Rheum emodi, haloperidol induced, catalepsy, locomotar activity.

QUICK RESPONSE CODE $\rightarrow$

DOI:

10.47583/ijpsrr.2022.v72i02.007

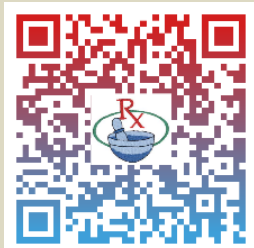

DOI link: http://dx.doi.org/10.47583/ijpsrr.2022.v72i02.007

\section{INTRODUCTION}

$D$ is the progressive neurodegenerative disorder caused as a consequence of degeneration of dopaminergic neurons in substantia nigra pars compacta (SNpc) in the mid brain ${ }^{1 .} \mathrm{PD}$ affected person shows motor symptoms such as rigidity, tremors at rest and gait disturbances as well as non-motor symptoms such as sleep disturbance, olfactory dysfunction, cognitive disturbance and CNS depression ${ }^{2}$ There is no effective cure for PD since currently available drugs can't stop and reverse the progression of the disorders and produce more side effects such as depression, confusion, hallucination, insomnia, anxiety, myocardial infractions and hepato toxicity ${ }^{3}$ Therefore the recent research mainly focused on searching newer drugs from plants having effective therapeutic properties against progression of disorder with less side effects. Neuroleptic-induced catalepsy has long been used as a model for the extrapyramidal side effects (EPS), such as parkinsonian-like catelepsy associated with antipsychotic use in humans. Evidences indicate that haloperidol induces catalepsy in animals, and this behavior response has long been used as a model for EPS effects. ${ }^{4-5}$

the present investigation was aimed to evaluate the protective capacity of herbal drug Rheum emodi against haloperidol induced Parkinson's disorder in rat.
Several studies reveal that Rheum emodi is rich in various flavonoids and has high antioxidant property. Recently, this plant showed acceptable result such anti-inflammatory, antibacterial antiulcer activity, ${ }^{6-15}$. In the present study, an attempt was made to evaluate antiparkinsonian activity of Rheum emodi in haloperidol-induced catalepsy.

\section{Plant Profile}

Rheum emodi is commonly used worldwide herb and often known as "the wondrous drug" because of its extensive medicinal uses. It consists of dried rhizome and root of some rheum species and their hybrid of family polygonaceae. The genus Rheum consists of approximately 60 perennial species distribution around the world; several species are used in medicine, some for culinary purpose and few others are grown as ornament; about ten species occur in India. ${ }^{16}$

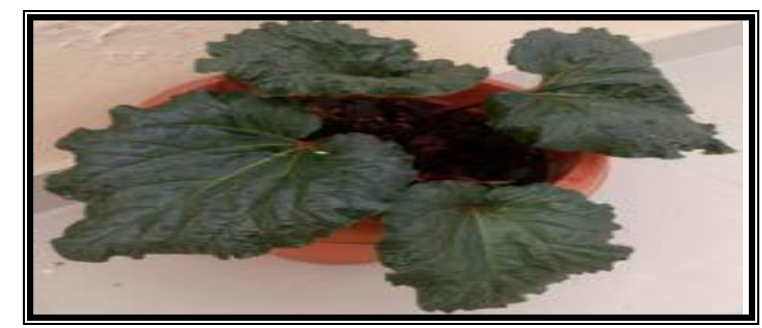

Figure 1: Rheum. emodi

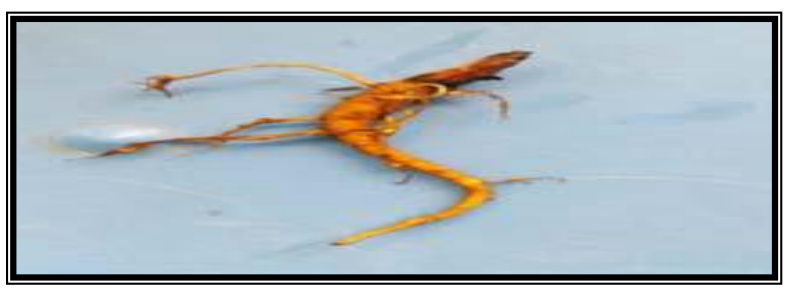

Figure 2: Rhizome of Rheum emodi 


\section{Plant description}

Rheum emodi or Himalayan rhubarb is known by various vernacular names in different geographical regions or system. ${ }^{17-23}$

Table 1: Vernaculars or Rheum emodi

\begin{tabular}{|c|c|}
\hline Language/System & Name \\
\hline English & $\begin{array}{l}\text { Indian Rhubarb or Himalayan } \\
\text { Rhubarb }\end{array}$ \\
\hline Sanskrit & Gandhini, Revatchini Hindi Dolu, Pita \\
\hline Kashmiri & Pumbehakh \\
\hline Tamil & $\begin{array}{l}\text { Nattu-ireval-chini, } \\
\text { chinni-kizhangu }\end{array}$ \\
\hline Telgu & Nattu-revalchini \\
\hline Arabic & Rewand \\
\hline Persian & Rewandchini \\
\hline Ayurvedic & $\begin{array}{l}\text { Amlaparni, pitamuuli, Gandhini } \\
\text { Revatikka }\end{array}$ \\
\hline Siddha & Revalchinikattai, Nattirevaichini \\
\hline Unani & Revandchini \\
\hline
\end{tabular}

\section{Classification}

Kingdom - Plantae

Clade - Angiosperm

Clade - Eudicots

Clade - Core eudicots

Order - Caryophyllales

Family - Polygonaceae

Genus - Rheum

Species - R. emodi

\section{Occurrence and distribution}

Rheum emodi is a stout herb, endemic to the Himalayan region distributed in the temperate and subtropical region from Kashmir to Sikkim at an elevation of 2800-3000m in India. It grows in the alpine zone on rocky soils, moraines and cervices. ${ }^{24-27}$

\section{Botanical description}

Rheum emodi Wall. ex Meissn, is a leafy perennial herb 1.5$3.0 \mathrm{~m}$ in height . Roots very stout. Radical leaves long petioled, very large, often $60 \mathrm{~cm}$ in diameter, orbicular or broadly ovate obtuse, base cordate 5-7 nerved, papillose beneath, subscaberulous above; petiole $30-45 \mathrm{~cm}$, very stout, scaberulous. Panicle is 0.6-0.9 m, papillosely puberulous, fastigiately branched and leafy with erect strict branches; flowers small $3 \mathrm{~mm}$ diameter, dark purple or pale red, in axillary panicles. Fruit ovoid-oblong, $13 \mathrm{~mm}$ long, purple,

base cordate, apex notched, wings narrower than the disk. Roots and rhizomes are the main parts used as drug and are collected in October to November. Root of Indian
Rhubarb is darker, inferior in aroma, coarser and untrimmed, is not decorticated. Fresh rhizome is 6 to 12 inches long, and the freshly fractured surface is dull orange to yellowish brown. ${ }^{28}$

\section{Phytochemistry}

Rheum emodi possess a number of phytoconstituents and these are: anthraquinones, anthrones, stilbenes, oxanthrone ethers and esters, flavonoids, lignans, phenols, carbohydrate and oxalic acid. The most common constituents of Rheum emodi are anthraquinone and stilbene. Anthraquinones include rhein, chrysophanol, aloe-emodin, emodin, physcion (emodin monomethyl ether), chrysophanein and emodin glycoside. Stilbene includes picetannol, resveratrol and their glycosides Different derivatives of oxanthrone include oxanthrone ether (revandchinone-4), oxanthrone esters (revandchinone-1 and revandchinone-2), and revandchinone- 3 .Other complex compounds have also been reported, including torachrysone 8-O-b-D-glucoside, sulfated anthraquinone glycoside sulfemodin 8-O-b-Dglucoside b-asarone and rhein 11-O-b-D-glucoside Tannins are also present in rhubarb Journal of Pharmacognosy and Phytochemistry which includes hydrolysable tannins, containing ester or glycosidic bonds composed of gallic acid, glucose and other monosaccharides and condensed tannins, derived primarily from the flavone derivatives catechin and leucocyanidin. ${ }^{28-32}$

\section{Pharmacological actions and traditional uses}

Rheum emodi is considered as purgative, stomachic, and astringent tonic. It also possesses aperient, emmenagogue and diuretic properties. Root is regarded as expectorant and appetizer. Anti-inflammatory, anti-dysentery and alexentric actions have also been ascribed. Rheum emodi is widely used in various traditional systems such as, Unani, Ayurveda, Chinese etc. Rheum emodi is used as a purgative and astringent tonic. Its primary action is of mild purgation; but it has also astringent property, so that it's secondary effect is to confine the bowels, hence it is well fitted for use in simple diarrhoea, but not in constipation or any affection in which a continuous aperients action is necessary. It is useful remedy in ailments of children. For the errors in diet of children and for the diarrhoea set up by undigested food, it is best given combined with sodium bicarbonate or magnesia. Rhein (4, 5Dihydroxyanthroquinone-2-carboxylic acid, is the only anthraquinone that is absorbed into cerebrospinal fluid of TBI (Traumatic Brain Injury) patients after Rheum emodi administration. Thus, rhein derived from Rheum emodi is responsible for most of the observed neuroprotection. Rheum emodi forms an important ingredient of a large variety of compound. Combined with ginger it may be given in the form of pills in cases where the bowels are sluggish. Root is regarded as panacea in local home remedies and is used in stomach problems, cuts, wound, and muscular swelling, tonsillitis and mumps. Some persons chew the root, and to them this is a very good way of taking it. Powdered roots are used for cleaning teeth

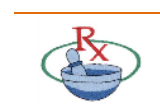


and sprinkled over ulcers for quick healing. Ethnomedically leaf-stalk, leaves and flowers are consumed as vegetables after cooking. In Assam its leaves consumed as vegetables and cultivated for this purpose. Leaves are also dried and stored for consumption along with other foods, or made into a preserve. It is however stated that cook stalks act as a powerful Purgative. Besides the medicinal uses, it is also used for coloration of textile and wooden material.

\section{MATERIALS AND METHODS}

\section{Collection and authentication of plant material}

The Powder of Rhizome of Rhubarb (Rheum emodi) had been procured from VHCA AYURVEDA LLP. Haryana.

\section{Experimental Animal}

The experiment was performed on wistar rats (weighing 150-250g), which were obtained from the animal house of Department of Pharmacology, Vidyabharati college of Pharmacy, Amaravati. All the animals were acclimatized to animal house prior to use. They are kept in cage in animal house with $12 \mathrm{~h}$ light: $12 \mathrm{~h}$ dark cycle. Animals were fed on pellets and tap water ad libitum. The care and handling of rat were in accordance with the internationally accepted standard guidelines for use of animals (CPCSEA) permission and approval for animal studies were obtained from the Institutional Animal Ethics Committee (IAEC) of Vidyabharati College of Pharmacy, Amaravati. SGB Amaravati University.

\section{Drugs and chemicals}

\section{Standard Drug}

1. Haloperidol injection IP (serenace) manufactured by RPG life science Ltd. was used to induce Parkinsonism in rats.

2. Levodopa and carbidopa tablet (syndopa 110) was used as standard drug.

\section{Other Chemical}

Saline water, Ethanol (90\%), DPPH, Ascorbic acid, $\mathrm{HCl}$, $0.1 \mathrm{~N} \mathrm{NaoH}$, chloroform, ferric chloride, $40 \%$ sodium hydroxide. The chemicals used and other solutions were all of analytical grade. All drugs and reagents were prepared immediately before use.

\section{Extraction method}

\section{Extraction of plant material by maceration method}

Maceration of $150 \mathrm{~g}$ of the powder of dried rhizome part of Rheum emodi in $350 \mathrm{ml}$ of Ethanol solvents was carried out. The mixture was shaken by an electrical shaker at room temperature for $48 \mathrm{~h}$. After that time, the mixture was filtered and the solvent was removed on a rotary evaporator. After drying the residue at $70^{\circ} \mathrm{C}$ in an electrical oven, a yellow powder was obtained.

\section{Solubility analysis}

The solubility analysis of ethanolic extract of Rheum emodi has been carried out using different solvent. Extract was found to be soluble in water, freely soluble in hot water.

\section{Determination of Acute Toxicity $L_{50}$}

The acute toxicity of prepared extract was performed using OECD guideline 425 in Following manner:

\section{Selection of Animal species \& housing:}

For the acute toxicity study the Female rats were used, as Female rats are more sensitive than Male rats. All the test animals were kept in separate cages at least 5 days before the commencement of toxicity test. Animals were maintained at $22 \pm 3^{\circ} \mathrm{C}$ in (12:12) light \&Dark cycle with free access of Food and Water.

\section{Preparation of doses}

During each study procedure Fresh aqueous solution of root extract of Rheum emodi was made and each time same volume of dose was administered by varying the conc. of the drug extract.

\section{Test procedure}

The required dose is administered in animal one at a time by using oral gavage The animal (Rats) were fasted overnight but water was not withdrawn. The fasted body weight of rat is determined and Dose is calculated on body weight basis after administration of Rheum emodi extract the food is withheld for further 3-4 h. For limit test 2000 $\mathrm{mg} / \mathrm{kg}$ dose was administered in one animal and then the animal was observed for mortality for a period of $48 \mathrm{~h}$ the tested rat was survived therefore test was continue by taking 4 more animals.

In main test dose of $1.75,5.5,17.5,55,175,550,2000$ was selected and was administered in animal one at a time. The animal was observed for any toxic symptoms initially for $1 \mathrm{~h}$. interval for $4 \mathrm{~h}$. then periodically for up-to 14 days.

\section{Selection of Dose groups}

1. On the basis of acute toxicity study data. It was conclude that $\mathrm{LD}_{50}$ of Rheum emodi extract is upto $2000 \mathrm{mg} / \mathrm{kg}$.

2. Therefore the test groups were divided as $100 \mathrm{mg}$ (low dose),200 mg (medium dose), 400mg (high dose).

\section{Determination of Antiparkinsons Activity}

The Antiparkinson's potential of ethanolic roots extract of Rheum emodi has been carried out by using haloperidol induce model in wistar rat of either sex weighing 150-250 gm. ${ }^{33}$

\section{Induction of experimental Parkinsonism}

Haloperidol causes dysfunctioning of various neurotransmitters such as acetylcholine, GABA, and serotonin. Pathology of haloperidol induced catalepsy underlying increased oxidative stress. Haloperidol, an 
antipsychotic drug, blocks central dopamine receptor in striatum. It also produces a behavioral state in rats in which they fail to correct externally imposed postures (called catalepsy); thus, keeping the above fact in mind, the haloperidol induced catalepsy model was selected. The method was followed for the anticataleptic activity. Wistar rats weighing 150-250g taken and haloperidol at a dose of $1 \mathrm{mg} / \mathrm{kg}$ i.p was administered chronically to the rats for a period of 14 days to induce PD. All the behavioural assessment was carried out on $4^{\text {th }}$ day, $8^{\text {th }}$ day and $14^{\text {th }}$ day of the study and the last behavioural quantification was done 24 hours after the last dose of Haloperidol.34

\section{Behavioural assessment}

\section{Cataleptic activity}

Bar test

Catalepsy, defined as a reduced ability to initiate movement and a failure to correct abnormal posture, was measured by means of the bar test. To test of catalepsy, animals were positioned so that their hindquarters were on the bench, and their forelimbs rested on a $1 \mathrm{~cm}$ diameter horizontal bar, 6-9 $\mathrm{cm}$ above the bench. The length of time that animal maintained this position was recorded by stopwatch to a maximum of $180 \mathrm{~s}$ (mean of three consecutive trials; interval: $1 \mathrm{~min}$ ). Animals would determine judge to be cataleptic if they maintained this position for $30 \mathrm{~s}$ or more. ${ }^{35}$

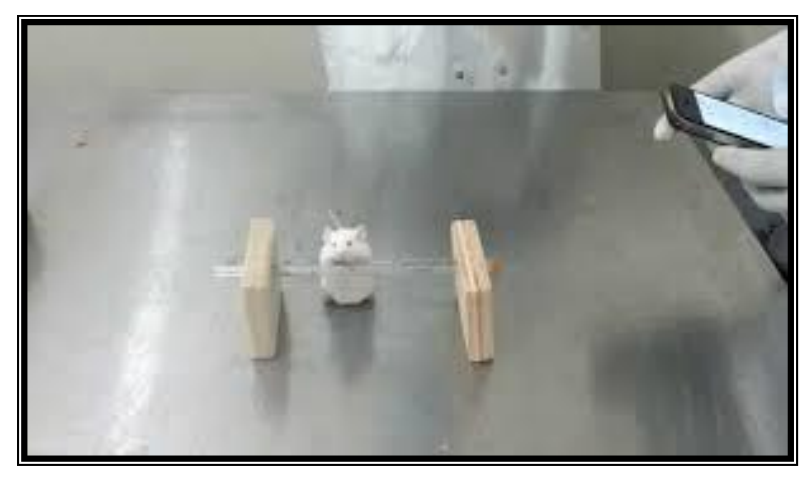

Figure 8: Bar Test

\section{Experimental design}

Rats were divided into six group with six animal in each. The first group received an oral dose of vehicle $(10 \mathrm{ml} / \mathrm{kg})$, second group received inducing agent (haloperidol $1 \mathrm{mg} / \mathrm{kg}$ ), third group received standard drug (levodopa+ carbidopa $10 \mathrm{mg} / \mathrm{kg}$ ) along with haloperidol $(1 \mathrm{mg} / \mathrm{kg})$, and fourth, fifth, and sixth group received extract of Rheum emodi at $100 \mathrm{mg}, 200 \mathrm{mg}, 400 \mathrm{mg} / \mathrm{kg}$

\section{Treatment protocol}

Briefly, the animal were divided into six groups $(n=6)$ and treated with respective test solutions as given below.
1. Group 1 ( Vehical control ) - Vehicle ( distilled water $10 \mathrm{ml} / \mathrm{kg})$ po

2. Group 2 ( Negative control) - Haloperidol $(1 \mathrm{mg} / \mathrm{kg}$ ) ip

3. Group 3(Positive control) - levodopa+carbidopa $(10 \mathrm{mg} / \mathrm{kg})+$ Haloperidol $(1 \mathrm{mg} / \mathrm{kg})$ ip

4. Group 4 (low dose) - $\operatorname{EERE}(100 \mathrm{mg} / \mathrm{kg}) \mathrm{po}+$ Haloperidol (1mg/kg)ip

5. Group 5 (Moderate dose) - EERE(200mg/kg)po + Haloperidol $(1 \mathrm{mg} / \mathrm{kg})$ ip

6. Group 6 ( Highest dose) - $\operatorname{EERE}(400 \mathrm{mg} / \mathrm{kg}) \mathrm{po}+$ Haloperidol $(1 \mathrm{mg} / \mathrm{kg})$ ip

\section{Statistical analysis}

All the data were expressed as mean \pm standard error of the mean. Statistical significance between more than two groups was tested using one-way ANOVA followed by the Dunnet's test.

\section{DISCUSSION}

In the present study, the animals which were treated for 14 days with haloperidol showed severe cataleptic responses. The pathogenesis of PD includes oxidative stress, protein accumulation like a-synuclein, mitochondrial dysfunction, apoptosis, and neuronal excitotoxicity. Among all, oxidative stress is a crucial pathological mechanism for PD.

In the present study, we evaluated the effect of EERE in haloperidol induced Parkinson disease in experimental animals. Haloperidol induced catalepsy is a widely accepted animal model of PD. Haloperidol (nonselectiveD2 dopamine antagonists) provides a pharmacological model of parkinsonism by interfering with the storage of catecholamine's intracellularly, resulting in dopamine depletion in nerve endings. In this study, haloperidol $(1 \mathrm{mg} / \mathrm{kg}$, i.p.) induced significant catalepsy in rats as evidenced by a significant increase in the time spent on the bar as compared to vehicle treated animals. Treatment with EERE significantly reduced the catalepsy in haloperidol treated rats in dose dependent manner. The EERE at doses of 100, 200 and $400 \mathrm{mg} / \mathrm{kg}$ showed protective effect against haloperidol induced catalepsy in bar test, indicated that this plant may have an ability to protect dopaminergic neurotransmion in striatum. EERE may also be effective in decreasing the oxidative stress in the haloperidol treated animals possibly due to its antioxidant activity. The phytochemical screening of EERE reveals presence of flavonoids and polyphenols such as Emodin and Aloemodin. Antioxidant activity of plant may be due to presence of these flavonoid and polyphenols which may be responsible for neuroprotection and preventing the oxidative stress in parkinsons diseases. 
Effect of extract of EERE on Catelepsy Bar Test on haloperidol induced catepsy in rat.

\begin{tabular}{|c|c|c|c|c|}
\hline Group & Treatment and doses & $\begin{array}{l}4 \text { th day Cateleptic score } \\
\text { No. seconds } / 3 \mathrm{~min} \text {. }\end{array}$ & $\begin{array}{l}8 \text { th day Cateleptic score } \\
\text { No. seconds/3min }\end{array}$ & $\begin{array}{l}14 \text { th day Cateleptic score } \\
\text { No. seconds } / 3 \mathrm{~min}\end{array}$ \\
\hline 1. & $\begin{array}{l}\text { Control (vehicle) } \\
10 \mathrm{ml} / \mathrm{kgpo} \text {. }\end{array}$ & $3.500 \pm 0.1693$ & $3.817 \pm 0.3081$ & $3.550 \pm 0.1996$ \\
\hline 2. & $\begin{array}{l}\text { Negative control } \\
\text { Haloperidol (1mg/kg i.p.) }\end{array}$ & $7.66 \pm 0.1333 \# \#$ & $58.267 \pm 2.683 \# \#$ & $113.73 \pm 6.2390 \# \#$ \\
\hline 3. & $\begin{array}{c}\text { Positive control } \\
\text { (Levodopa+Carbidopa), } \\
10 \mathrm{mg} / \mathrm{kg}, \text { i.p)+ } \\
\text { Haloperidol (1mg/kg i.p.) }\end{array}$ & $3.550 \pm 0.1996$ & $23.66 \pm 0.5315$ & $78.267 \pm 0.2963$ \\
\hline 4. & $\begin{array}{c}\text { EERE }(100 \mathrm{mg} / \mathrm{kg}) \\
+ \\
\text { Haloperidol }(1 \mathrm{mg} / \mathrm{kg} \text { i.p. })\end{array}$ & $5.183 \pm 0.3049 * * * *$ & $47.867 \pm 1.491 * * * *$ & $95.750 \pm 0.2232 * * * *$ \\
\hline 5. & $\begin{array}{c}\text { EERE.(200mg/kg)+ } \\
\text { Haloperidol }(1 \mathrm{mg} / \mathrm{kg} \text { i.p.) }\end{array}$ & $4.367 \pm 0.1687^{* * * *}$ & $35.233 \pm 0.9898 * * * *$ & $85.117 \pm 0.1400 * * * *$ \\
\hline 6. & $\begin{array}{c}\text { EERE.(400mg } / \mathrm{kg}) \\
+ \text { Haloperidol }(1 \mathrm{mg} / \mathrm{kg} \text { i.p) }\end{array}$ & $3.683 \pm 0.1721 * * * *$ & $24.300 \pm 0.5774 * * * *$ & $79.967 \pm 0.1358 * * * *$ \\
\hline
\end{tabular}

Values are expressed as mean \pm SEM, one-way ANOVA followed byDunnett's test multiple comparison test, ${ }^{* * * *}$ indicates $P<0.001$ when compare to Negative control. \#\# indicates $P<0.001$ when compare to control group.

Day 4

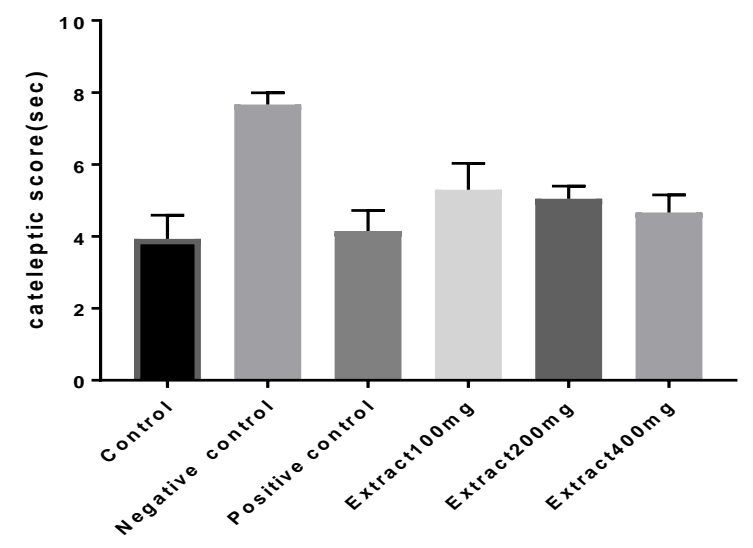

Graph 1 : Effects of extract of EERE on Catelepsy Bar Test in haloperidol induced catepsy in rat .

$$
\text { Day - } 8
$$

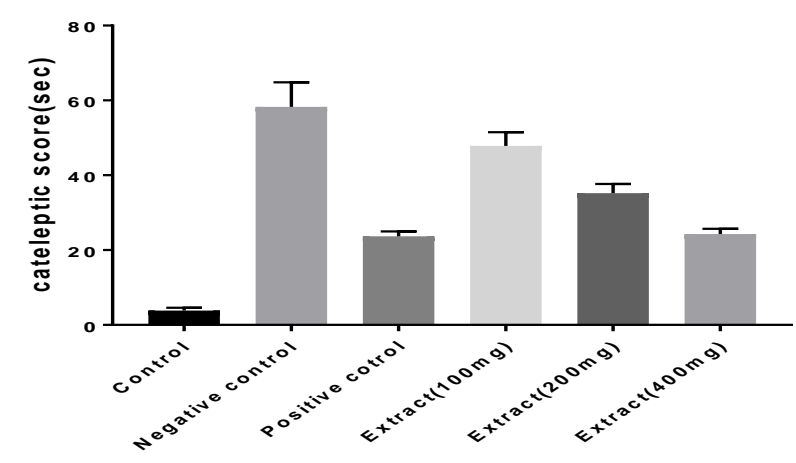

Graph 2: Effect of extract of EERE on Catelepsy Bar Bar Test in haloperidol induced catepsy in rat
Day 14

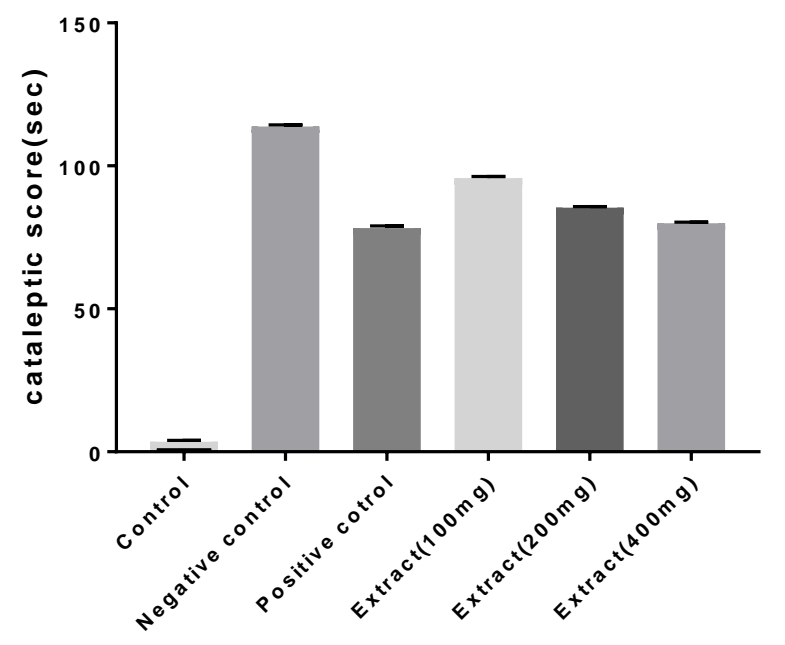

Graph 3: Effects of extract of EERE on Catelepsy Bar Test in haloperidol induced catepsy in rat 14 th day.

\section{CONCLUSION}

Ethanolic extract of Rheum emodi significantly reduced the symptoms of Parkinsons disease may be due to antioxidant and neuroprotective activities or increase in the level of brain dopamine similar to L-dopa and carbidopa. Thus, Ethanolic extract of Rheum emodi may have therapeutic potential in the treatment of PD. Further, it is necessary to estimate the brain dopamine level and isolate the individual constituents responsible for neuroprotective potential, and also characterization of active constituents responsible for neuroprotective effect. It could be the next better, safer \& cheaper herbal alternate in management of Parkinsonism and also modulation of herbal drug with dopaminergic agonist to potentiate the activity. 


\section{REFRENCES}

1. Lees AJ. Unresolved issues relating to the shaking palsy on the celebration of James Parkinson's 250th birthday. Movement disorders: official journal of the Movement Disorder Society. 2007; 22(S17): S327-34.

2. Leenders KL, Oertel WH. Parkinson's disease: clinical signs and symptoms, neural mechanisms, positron emission tomography, and therapeutic interventions. Neural plasticity. 2001 Jan 1; 8(1-2): 99-110.

3. Kui lu1, Cheng Zhang, Wenjun Wu, Min Zh, Yamei Tang and Ying Peng Department J AKm Coll Neurology, Zhongshan City People's Hospital, Zhongshan, Guangdong.,( 2014).

4. Datla KP, Zbarsky V, Rai D, Parkar S, Osakabe N, Aruoma OI, Dexter DT. Short-term supplementation with plant extracts rich in flavonoids protect nigrostriatal dopaminergic neurons in a rat model of Parkinson's disease. Journal of the American College of Nutrition. 2007 Aug 1; 26(4): 3419.

5. Parvaiz A. Wani, Irshad A. Nawchoo and B.A.Wafai. The Role of Phenotypic Plasticity, Phenology, Breeding Behaviour and Pollination Systems in Conservation of Rheum emodiWall. exMeisn. (Polygonaceae) - A Threatened Medicinal Herb of North West Himalaya. The International Journal ofPlant Reproductive Biology (2009); PP: 1(2): 179-189

6. Das D, Maulik SR, Bhattacharya SC. Colouration of wool and silk with Rheum emodi. Phytochemistry. 2006; 66(3):33-7.

7. Malik S, Sharma N, Sharma UK, Singh NP, Bhushan S, Sharma M, Sinha AK, Ahuja PS. Qualitative and quantitative analysis of anthraquinone derivatives in rhizomes of tissue culture-raised Rheum emodi Wall. plants. Journal of plant physiology. 2010 Jun 15; 167(9): 749-56.

8. KS, Srinivas PV, Praveen B, Kishore KH, Murty US, Rao JM. Antimicrobial constituents from of Rheum emodi. the rhizomes Phytochemistry. 2003 Jan 1; 62(2): 203-7.

9. Singh SS, Pandey SS, Singh $R$, Aggarwal $S$. 1, DihydroxyanthraquinoneDerivates from 1496.theRhizome of Rheum emodiwall. Indian Journal of Chemistry (2005) PP ; 42B: 1494-CP. Indian medicinal plants: an illustrated dictionary. Springer Science Business Media; 2008 Apr 22.

10. Kaur A, Kumar S, Sharma R. Assessment of anti-ulcer activity of Rheum emodii rhizomes extract. Indo Global Journal of Pharmaceutical Sciences. 2012; 2(3): 333-41.

11. Akhtar MS, Amin $M$, Ahmad $M$, Alamgeer $A$. Hepatoprotective effect of Rheum emodi roots (Revand chini) and Akseer-e-Jigar against paracetamol-induced hepatotoxicity in rats. Ethnobotanical leaflets. 2009; 2009(2): 3.

12. Kounsar F, Rather MA, Ganai BA, Zargar MA. Immunoenhancing effects of the herbal extract from Himalayan rhubarb Rheum emodi Wall. ex Meissn. Food chemistry. 2011 Jun 1; 126(3): 967-71.

13. KuiLui,Cheng Zhang, Wenjun Wu, Min Zhou, Yamgi Tang and Yin department of Neurology, Zhongshan City People's Hospital, Zhongshan, Guangdong August 14, (2014).
14. Mukherjee PK, Nema NK, Maity N, Sarkar BK. Phytochemical and therapeutic potential of cucumber. Fitoterapia. 2013 Jan 1; 84: 227-36.

15. Aslam M, Dayal R, Javed K, Fahamiya N, Mujeeb M, Husain A. Pharmacognostical and phytochemical evaluation of Rheum emodi Wall. Journal of Current Pharma Research. 2012; 2(2): 471.

16. Ye M, Han J, Chen H, Zheng J, Guo D. Analysis of phenolic compounds in rhubarbs using liquid chromatography coupled with electrospray ionization mass spectrometry. Journal of the American Society for Mass Spectrometry. 2007 Jan; 18(1): 82-91.

17. Qin $Y$, Wang JB, Kong WJ, Zhao YL, Yang HY, Dai CM, Fang $\mathrm{F}$, Zhang $\mathrm{L}$, Li BC, Jin C, Xiao XH. The diarrhoeogenic and antidiarrhoeal bidirectional effects of rhubarb and its potential mechanism. Journal of ethnopharmacology. 2011 Feb 16; 133(3): 1096-102.

18. Prior M. Rhubarbaria recipes for rhubarb. Prospect books; 2009, Ibrahim M, Khaja NM, Aara A, Khan AA, HabeebMA, Devi PY. Hepatoprotective activity of Sapindus mukorossi and Rheum emodi extracts. World J Gastroenterol (2008); PP: 14(16): 2566-2571.

19. Dymock W, Warden $\mathrm{CJH}$, Hooper D. Pharmacographica Indica. A history of the principal drugs of vegetable origin. Vol III. New Delhi:Shrishti Book Distributors;( 2005), PP 153-157.

20. Fang $F$, Wang JB, Zhao YL, Jin $C$, Kong WJ, Zhao HP, Wang $\mathrm{HJ}$, Xiao XH. A comparative study on the tissue distributions of rhubarb anthraquinones in normal and $\mathrm{CCl} 4$-injured rats orally administered rhubarb extract. Journal of ethnopharmacology. 2011 Oct 11; 137(3): 1492-7.

21. Najmul Ghani, KhazianulAdvia. Lucknow: MunshiNaval Kishore Press; YNM. 750-753. IbnBaitar. Jami al Mufradat al Adviawa al Aghzia(Urdu Translation). Vol II. New Delhi: CCRUM; (2000); PP: 275-282.

22. Sina I. Al Qanoon Fil Tib (Urdu trans. by Kantoori GH). New Delhi: Ejaz Publication house. 2010: 447-8.

23. Nadkarni KM. Indian plants and drugs. Ajay Book Service;

24. Khare CP. Indian medicinal plants: an illustrated dictionary. Springer Science \& Business Media; 2008 Apr 22.

25. Medicinal plants in folklores of Kashmir Himalayas.1sted. New Delhi: CCRUM; (2001), PP: 184

26. Sri MD, Khair S. Standardization and HPTLC. Fingerprinting study of Poly Herbal Unani Formulation-Habb-e-Sara Khas.

27. Khare CP. Indian Medicinal Plants: An IllustratedDictionary. New Delhi: Springer India (P) Ltd; (2007) PP: 543-44.

28. Radhika R, Krishnakumari S, Umashankar V, Sudarsanam D. Effect of enzymatic antioxidants of Rheum emodiin alloxan induced diabetic rats. Int J Biol Chem Sci. 2010 Dec; 4(6): 1905-3.

29. Rajkumar V, Guha G, Ashok Kumar R. Antioxidant and anticancer potentials of Rheum emodi rhizome extracts. Evidence-Based Complementary and Alternative Medicine. 2011 Jan 1; 2011.

30. Kïrtikara KR, Basu BD, An IC, Blatter E, Caius JF, Mhaskar KS. Indian medicinal plants, with illustrations. 
31. Nadkarni KM. Indian plants and drugs. Ajay Book Service; 2010.

32. Shah C, Kumar S, Battiwala A. Evaluation of Anti-ulcer activity of Rosa Centifolia (Linn.) flowers in experimental rats. Journal of Natural Remedies. 2012 Jan 1; 12(1): 20-9.

33. Momin FN, Kalai BR, Godse VS, Patole NS, Shikalgar T, Naikwade NS. Gastroprotective Effect of Mimosa Pudica Leaves Extract on in-vivo Test Models in Rats. Journal of Biologically Active Products from Nature. 2011 Jan 1; 1(3): 160-7.
34. Awounfack CF, Ateba SB, Zingue S, Mouchili OR, Njamen D. Safety evaluation (acute and sub-acute studies) of the aqueous extract of the leaves of Myrianthus arboreus P. Beauv.(Cecropiaceae) in Wistar rats. Journal of ethnopharmacology. 2016 Dec 24; 194: 169-78.

35. Shireen E, Haleem DJ. Reversal of haloperidol-induced motor deficits by mianserin and mesulergine in rats. Pak J Pharm Sci. 2011 Jan 1; 24(1): 7-12.

Source of Support: The author(s) received no financial support for the research, authorship, and/or publication of this article.

Conflict of Interest: The author(s) declared no potential conflicts of interest with respect to the research, authorship, and/or publication of this article.

For any question relates to this article, please reach us at: globalresearchonline@rediffmail.com New manuscripts for publication can be submitted at: submit@globalresearchonline.net and submit_ijpsrr@rediffmail.com 